\title{
АНАЛІЗ СТАНДАРТИЗОВАНОГО ПСИХОДІАГНОСТИЧНОГО ІНСТРУМЕНТАРІЮ У СФЕРІ ГЕНДЕРНИХ ДОСЛІДЖЕНЬ
}

\author{
Тетяна Костіна \\ кандидат психологічних наук, доцент, \\ докторант кафедри психології \\ ДВНЗ «Переяслав-Хмельницький державний педагогічний \\ університет імені Григорія Сковороди» \\ 08401, Україна, м. Переяслав, вул. Сухомлинського, 30 \\ kostina tanya@ukr.net, https://orcid.org/0000-0001-9644-0630
}

\begin{abstract}
Анотація
Статтю присвячено аналізу методичного інструментарію, який використовується у сфері гендерних досліджень. Проведено теоретичний аналіз можливостей використання методів та методик, що використовуються у західній психології. Зокрема, представлені основні методики, які на сьогодні застосовуються у психології гендерних досліджень: Bem SexRole Inventory (BSRI), Implicit Association Test (IAT), Gender Bias Quiz.

Підкреслено, що при дослідженні гендерно чутливих питань (гендерна нерівність, гендерна дискримінація, гендерний дисбаланс тощо) варто поєднувати експліцитні методи дослідження (прямі запитання, пряме шкалування, пряме оцінювання) із використанням імпліцитних (використовують опосередкований механізм для вимірювання не усвідомлених установок). Серед проаналізованих у роботі методик, до експліцитних належать Bem Sex-Role Inventory (BSRI), Gender Bias Quiz; до імпліцитних - Implicit Association Test (IAT).

Особливого значення при дослідженні ставлення особистості до гендерної проблематики (зокрема, до гендерної нерівності) набувають методичні прийоми i техніки, які дозволяють отримати інформацію, яку надає людина поза межами ефекту соціального схвалення. Зазначено, що процедура такого дослідження є більш складною та потребує від науковця вміння провадити якісний аналіз, що дозволяє виявляти часто приховані чинники поведінкових проявів. Проведений науковий пошук показав, що при дослідженні гендерної проблематики (гендерні стереотипи, ставлення до гендерної нерівності, гендерного дисбалансу тощо) важливо поєднувати методи, що дозволяють отримати як кількісні показники (наприклад, рівень прояву гендерних упереджень), так і якісні, що можуть бути отримані за допомогою інших методів, наприклад, методу контент-аналізу.
\end{abstract}

Ключові слова: гендер, гендерні дослідження, експліцитний метод, імпліцитний метод, методичний інструментарій для гендерних досліджень.

\section{Вступ}

В парадигмі розвитку сучасного суспільства все більше актуалізується питання аналізу та пошуку векторів розгортання людської спільноти. Особливо гостро це постає на теренах України: не зважаючи на зміни, що відбулися у 2013-2014 роках, питання вектору, який обирає для себе українська спільнота ще й досі вимагає значних переосмислень. I 
особливого значення це набуває у сфері гендерних досліджень. Адже, ще й досі лунають сексистські висловлювання від представників політичної (i, не лише політичної) еліти, що ставить під сумнів можливість наближення до європейських стандартів у комунікації, взаємодії та поваги до унікальності кожної особистості (не залежно від статі).

На сьогодні у сфері гендерних досліджень (gender studies) широко застосовуються різноманітні методи та прийоми, вибір яких зумовлюється приналежністю науковця до тієї або іншої школи та галузі знань. Зокрема, психологічна наука збагатилася теоретичними підгрунтям та практичними відкриттями, що були реалізовані у межах антропології (переосмислення антропоцентризму), економічної теорії (фемінізація бідності, економічна залежність жінок тощо), культурології (культурна гендерна стереотипізація), соціології (гендер як соціальний конструкт), фемінізму (боротьба за рівність), філософії (переосмислення концепції андроцентризму).

Сучасний стан психологічних досліджень у сфері гендерної проблематики має значний дисбаланс: величезна кількість теоретичного підгрунтя та досить обмежений психодіагностичний інструментарій. Під психодіагностичним інструментарієм ми розуміємо стандартизовані методики (тести, опитувальники), які можна використати для виявлення тих або інших гендерних особливостей людини. Це ті методики, результати яких будуть сприйняті науковою психологічною спільнотою.

Сучасна психологічна наука у контексті гендерних досліджень вміщує наступний парадокс: часто використання методів, які властиві певній науковій школі, є практично неможливими для психолога через відсутність у неї/нього відповідної спеціалізованої підготовки. Наприклад, гендерна проблематика представлена у працях психоаналітика Ж. Лакана, де він розвиває теорію суб'єктивності та визначає символічне у формуванні гендерної ідентичності та пропонує для використання схему (тріаду): «уявне» «символічне» - «реальне» (Lacan, 1972). Проте використання лакановських напрацювань $\epsilon$ неможливим без грунтовної підготовки, яку психолог має отримати у відповідності до процесу сертифікації у психоаналізі (зрозуміло, що не всі фахівці у сфері психології прагнуть стати психоаналітиками). Ця ситуація, на нашу думку, є достатньо обмежуючого для психолога-науковця.

Однак, одночасно з обмеженнями, психологія має свої переваги у порівнянні 3 іншими науками, які досліджують гендерне питання (соціологія, культурологія, політологія, економіка тощо) - це можливість віднайти особистісну (персональну) складову. Розуміння специфіки ставлення людини до гендерної нерівності, проявів гендерної дискримінації, наявних гендерних установок дозволять визначити точки зростання українського суспільства та окреслити шлях його розвитку.

Мета дослідження: здійснити теоретичний аналіз особливостей використання стандартизованого психодіагностичного інструментарію у сфері гендерних досліджень. Завдання дослідження: 1) проаналізувати стандартизовані методики, що використовуються у Західних країнах у сфері гендерних досліджень; 2) визначити можливості їх використання на теренах України.

\section{Методи дослідження}

В дослідженні (для досягнення поставленої мети) застосовувалися такі методи дослідження: системно-структурний аналіз, узагальнення даних наукової літератури щодо 
методичних засад реалізації досліджень у сфері гендерної проблематики. Проведений аналіз дозволив виділити основні методичні підходи, які використовуються у психологічних дослідженнях, зокрема при вивченні гендерної специфіки того, чи іншого явища. Так, у психології західних країн методи дослідження, зазвичай, розподілені на: методи непрямої взаємодії з досліджуваним (Unobtrusive Measures) та активні методи (Reactive Methods) (Webb, 1973).

Загальним правилом для методів непрямої взаємодії $\epsilon$ те, що досліджуваний/на не знає про те, що є учасником/цею дослідження. Методи непрямої взаємодії, у свою чергу, розподілені на приховані та опосередковані. До прихованих відносять структуроване спостереження, при якому досліджуваний не знає, що за ним ведеться спостереження. Опосередковані включають у себе аналіз даних, які дослідник може здобути без посередньої взаємодії із досліджуваним (аналіз фото, документів, архівних даних (у тому числі контент-аналіз) тощо). Пряма взаємодія включає використання опитувальників, тестів, інтерв'ю, бесіди. Як бачимо, це означає пряме контактування із учасниками дослідження (респондентами) (Taylor, Bogdan \& DeVault, 2015). Отже, бачимо, що збір даних може відбуватись за різними стратегіями у відповідності до цілей і мети дослідження. Необхідно підкреслити, що процедура та хід дослідження має бути логічно продуманим і структурованим, що сприятиме збору достовірних даних.

Зазначимо, що для досліджень у сфері гендерної проблематики кращим $\epsilon$ поєднання як активних методів, так i методів непрямої взаємодії. В цій статі проаналізовані та зазначені основні методи, що можуть бути використані при дослідженні у сфері гендерної проблематики (наприклад, психологічні особливості ставлення до гендерної нерівності представників певної вікової категорії, аналіз гендерних упереджень за статевою ознакою тощо). У статті здійснено аналіз методичних можливостей опитувальника «Bem Sex-Role Inventory»(BSRI) для вивчення гендерних ролей особистості; тесту «Implicit Association Test» (IAT) - для дослідження підсвідомих гендерних упереджень; опитувальника «Gender Bias Quiz» - визначення особливостей гендерних переконань людини та рівня їх прояву.

\section{Результати та дискусії}

В дослідженні, яке розкривається у даній статті, актуалізується питання необхідності використання надійних методик у сфері вивчення гендерної проблематики (зокрема, при дослідженні ставлення людини до питання гендерної нерівності). Особливого значення набувають методичні прийоми та техніки, які дозволяють отримати інформацію, яку надає респондент поза межами ефекту соціального схвалення. Процедура такого дослідження є більш складною та потребує від науковця вміння проводити якісний аналіз, що дозволяє виявляти часто приховані чинники поведінкових проявів.

Для більш високої надійності та валідності психологічні дослідження у сфері гендерної проблематики мають включати як кількісні, так і якісні складові. Кількісна складова забезпечується відповідною вибірковою сукупністю із подальшим статистичним аналізом. Статистичний аналіз має опиратись на описові показники: кількість респондентів (N); міри центральної тенденції: мода, медіана, середнє арифметичне. Зазначимо, що у більшості дослідженнях (як вітчизняних, так і зарубіжних) мірою центральної тенденції, зазвичай, обирають медіану, що пов'язано із більшою 
«статичністю» (невразливістю до «викидів» у даних вибіркової сукупності) даного показника у порівнянні із середнім арифметичним та модою; варіативності вибірки (розмах, дисперсія).

Крім того, обов'язковою умовою наукового дослідження $\epsilon$ застосування відповідних статистичних критеріїв для визначення наявних зв'язків (наприклад, кореляційний аналіз) або достовірних відмінностей (наприклад, t-критерій Стьюдента) між даними 3 їх подальшою інтерпретацією (Taylor, Bogdan \& DeVault, 2015). 3бір первинних даних має відбуватись на основі відповідних методик, які дозволяють знайти відповідь на поставлене емпіричне питання (гіпотезу). Отже, дослідження психології ставлення людини до гендерної проблематики має містити у себе як стандартизовані методики, так і якісну компоненту.

До стандартизованих та загально вживаних методик, що можуть бути використані при дослідженні гендерної проблематики можна виділити наступні: опитувальник Вет Sex-Role Inventory (BSRI), Implicit Association Test (IAT), Gender Bias Quiz. До методів, що сприяють отриманню якісних даних при дослідженні гендерної проблематики доречно використовувати архівний метод, різновидом якого є контент-аналіз. У даній роботі зосередимо увагу на аналізі методик, які дозволяють отримати кількісні показники, які, зрозуміло, у подальшому дають можливість здійснити інтерпретації із залученням генетичного, структурного чи структурно-генетичного методів аналізу.

На сьогодні опитувальник Bem Sex-Role Inventory (BSRI) позначають, як такий, що визначає психологічну стать особистості. Методика вміщує 60 запитань та складається із трьох блоків по 20 запитань, які визначають приналежність людини до одного із трьох типів психологічної статі: 1) психологічна чоловіча стать позначається під терміном маскулінність (маскулінний тип), куди відносяться традиційні прояви чоловічих рис: активність, впевненість, цілеспрямованість, лідерство тощо; 2) психологічна жіноча стать позначається під терміном фемінність (фемінний тип) та вміщує у собі такі «жіночі» характеристики, як: пасивність, залежність, емоційність тощо; 3) психологічна стать, що гармонійно поєднує класичні «чоловічі» та «жіночі» прояви позначена як андрогінність (Bem, 1993). Зазначимо, що до цієї категорії відносились ті опитувані, які набрали високі показники як за шкалою маскулінність, так і за шкалою фемінність. Також С. Бем виділила категорію людей, які демонстрували слабо виражені риси за кожною зі шкал (маскулінність-фемінність), такий варіант психологиня позначила як «недиференційована» психологічна стать (Bem, 1993). Отже, дана методика дозволяє визначити як саме людина ідентифікує себе психологічно (а не лише на рівні біологічної статі). Оскільки методика була розроблена у 80-ті роки, відбуваються дослідження, які спрямовані на виявлення особливостей застосування даної методики у сучасних умовах (Auster \& Ohm, 2000; Ferrer-Pérez, 2014). Перевагою використання BSRI є те, що їі можна використовувати у крос-культурних дослідженнях, оскільки вона перекладена та адаптована значною кількістю мов.

Дослідження у гендерній сфері вимагає від науковця добору методик, які надають можливість отримати реакції досліджуваних, які знаходяться поза межами особистісного контролю та соціально схвальної реакції. Такі відповіді досить складно отримати лише на основі опитувальників, оскільки у них людина певною мірою може передбачити «наслідки» своєї відповіді та реалізує відповіді у соціально заданих поняттях, щоб 
зберегти своє «обличчя». За таких умов завжди актуальним залишається питання надійності отриманих відповідей. Саме тому у психології наявні методи, використання яких дозволяє «обійти» соціально очікувані відповіді респондентів. Такого роду методики працюють на рівні несвідомих установок та переконань, які проявляються при взаємодії із стимульним матеріалом; в результаті отримуються, так би мовити, «чисті» дані. У більшості випадків такі методики належать до проективних i працюють iз неструктурованим стимульним матеріалом (тест Роршаха, ТАТ, САТ тощо).

Якщо при звичайному опитуванні респондент може зазначити, що для нього/неї не притаманні гендерні дискримінаційні переконання та упередження, навіть, якщо вони у неї/нього насправді наявні. Та бажання бути «хорошим/хорошою» роблять свою справу i людина дає відповідь, яка відповідає соціальним нормам (наприклад, норма прийняття іншої людини, іiі унікальності, повага до неповторності кожної людини). За такого ходу дослідження науковцю складно визначити дані на ті, які відповідають особистості досліджуваного, або жє лише проявом бажання соціального схвалення.

Одним із методів, що працює на рівні несвідомих упереджень особистості $€$ Implicit Association Test (IAT), який ще називають Hidden Bias Tests (Project Implicit, 1998). Даний тест був розроблений в рамках проекту Project Implicit, який був заснований у 1998 році такими науковцями, як: Tony Greenwald (University of Washington), Mahzarin Banaji (Harvard University), and Brian Nosek (University of Virginia). На сьогодні проект розміщений на платформі сайту Гарвардського університету. Основною ідеєю даного проекту було вивчення несвідомих соціальних установок, притаманних людям. Запропонований тест (точніше об'єднання тестів) дозволяє визначити гендерні стереотипи, які притаманні особистості; крім того метод дозволяє дослідити расові, релігійні стереотипи, ставлення до людей з особливими потребами тощо. Наявність у назві методики терміну «іmplicit» (імпліцитний) підкреслює, що вона працює 3 неусвідомлюваними установками та використовує для їх вимірювання опосередкований механізм. На противагу імпліцитним, експліцитні методи працюють на рівні свідомого матеріалу, i, зазвичай, використовуються у вигляді опитування (усного/письмового). У нашому випадку до експліцитних методик відносяться Bem Sex-Role Inventory (BSRI) та Gender Bias Quiz. Однак, як було зазначено вище, при дослідженні соціальних стереотипів (у тому числі гендерних) процедура дослідження має включати методи та методики, що працюють із глибинним, «прихованим» матеріалом людини.

Виявлення наявності/відсутності соціальних стереотипів відбувається на основі аналізу середніх показників (швидкості реакції) на інформацію, яка демонструється досліджуваному. Структуру та процедуру дослідження вибудовано таким чином, щоб отримати надійні та валідні дані у ході використання даної методики (кількість запитань, порядок їх демонстрації, збір даних про учасника дослідження: вік, стать, раса, освіта тощо). Мінусом даного тесту є його відсутність українською мовою, що ускладнює використання у вітчизняних дослідженнях. Використання можливе із респондентами, які знають російську, оскільки методика доступна в російськомовному варіанті. Однак, підкреслюється, що вона проходить стадію адаптації і при отриманні результатів необхідно пам'ятати, що кожні результати треба коректно інтерпретувати.

При розробці методики Implicit Association Test (IAT) науковці спиралися на дані психологічних досліджень, які показують наявність тих або інших упереджень (англ. 
«bias»), які не є усвідомлюваними та здійснюють вплив на поведінку людини. Одним із прикладів $\epsilon$ расові упередження на теренах США: у більшості випадків американці приписують позитивні риси білим американцям, а негативні - афроамериканцям. Накопичені дані у сфері расових упереджень сприяли поширенню досліджень у сфері гендерно зумовлених стереотипів, зокрема, у ставленні людей до «жіночого» лідерства, які широко висвітлюються у межах The American Association of University Women (AAUW) (Hill, 2016). Наприклад, якщо людина пов’язала слова «наука» та «чоловік» (що, насправді, демонструє більшість респондентів), то при інтерпретації результатів потрібно показати наявний стереотип, однак необхідно звернути увагу досліджуваного на те, як часто певні стереотипні очікування присутні в нашій особистості, які ми часто не піддаємо критичному аналізу. I не через те, що ми не хочемо їх проаналізувати, а через те, що ці упередження знаходяться на глибинному рівні, який доступний лише за допомогою такого роду тестів. Зустріч із подібними шаблонами дозволяє людині подивитись поіншому на ситуацію різних соціальних очікувань по відношенню до жінок та чоловіків (у контексті вивчення гендерної проблематики).

Одним із найбільш уживаних у закордонній психологічній науці у сфері гендерних досліджень є опитувальник Gender Bias Quiz, який використовується для дослідження гендерних стереотипів особистості (Gender Bias Quiz, 2015). Окрім вивчення наявності певного рівня гендерно зумовлених упереджень, метою даного інструментарію було підвищення рівня усвідомлення наявних стереотипів та шаблонів на основі отриманих даних. Структура методики побудована таким чином, що навпроти кожного рівня надається не лише його опис, а й зазначається над чим ще може попрацювати особистість (у межах гендерного питання).

Даний опитувальник був розроблений і виданий у Канаді у 2015 році за підтримки міжурядової організації The Commonwealth of Learning (COL), метою якої є підвищення освітніх можливостей серед населення, яке його потребує. Опитувальник складається із 20 тверджень, кожне з яких респонденту пропонується оцінити за шкалою від 1 до 4: де 1 повністю не погоджуюсь, 2 - частково не погоджуюсь, 3 - частково погоджуюсь, 4 повністю погоджуюсь. На початку проходження опитувальника в інструкції наголошується на тому, щоб досліджуваний відповідав/ла так, як вважає саме він/вона, а не так, як, зазвичай, прийнято у соціумі. Дана методика має плюсом те, що дає градацію того, якою мірою притаманні гендерні стереотипи для людини, що пройшла тест. Загалом виділені чотири категорії, які позначають певний рівень присутності гендерних упереджень (від низького до високого рівня вираженості гендерних упереджень). Крім того, отримавши результат респонденту, окрім опису існуючої ситуації, надаються рекомендації щодо того, як сприяти зниженню вираженості гендерних упереджень. Мінусом даної методики (як і методики Bem Sex-Role Inventory) є те, що респондент може «підлаштувати» власні відповіді на питання у відповідності до соціальних очікувань. Таким чином, результати будуть свідчити не про те, що думає (вважає) респондент, а про те, що він/вона хоче, щоб думали про неї/нього. Через це використання даної методики краще поєднувати з іншими методами, які дозволять отримати додаткові дані. Такі дані можна отримати із використанням методів, які дозволяють отримати якісну складову ставлення до гендерної проблематики особистості, наприклад, контент-аналіз. 


\section{Висновки}

За результатами проведеного теоретичного дослідження було проаналізовано стандартизовний психодіагностичний інструментарій, який доцільно використовувати у контексті вивчення гендерної проблематики (Bem Sex-Role Inventory (BSRI), Implicit Association Test (IAT), Gender Bias Quiz).

Зазначено, що у психології західних країн методи дослідження розподілені на методи непрямої взаємодії з досліджуваним (Unobtrusive Measures) та активні методи (Reactive Methods). Визначено, що отримання інформації від респондентів може здійснюватись на основі використання експліцитних (прямі запитання / пряме шкалування) або імпліцитних (використовують опосередкований механізм для вимірювання неусвідомлених установок) методів дослідження. Прикладом останнього є Implicit Association Test (IAT), який активно використовується у західній психології.

Підкреслено, що при дослідженні гендерної проблематики (гендерні стереотипи, ставлення до гендерної нерівності, гендерного дисбалансу тощо) важливо поєднувати методи, що дозволяють отримати як кількісні показники (наприклад, рівень прояву гендерних упереджень), так і якісні, що можуть бути отримані за допомогою інших методів, наприклад, методу контент-аналізу.

Перспективи подальших досліджень вбачаємо у адаптації зазначених методик для використання на теренах України: адаптація українською мовою, стандартизація розподілу шкал, уточнення вікових меж застосування тощо.

\section{Література}

1. Auster, C.J., \& Ohm, S. (2000). Masculinity and femininity in contemporary American society: A reevaluation using the Bem Sex-Role Inventory. Sex Roles, 43, 499-528.

2. Bem, S. (1993). The Lenses of Gender: Transforming the Debate on Sexual Inequality. Yale University Press.

3. Ferrer-Pérez, V.A. (2014). The measure of the masculinity-femininity construct today: Some reflections on the case of the Bem Sex Role Inventory. Revista de Psicología Social 29(1): 180-207, 2014. DOI: 10.1080/02134748.2013.878569

4. Gender, Bias Quiz (2015). The Institutional Scorecard for Gender Mainstreaming / written by K. Tezare; edited by R. Wong. Commonwealth of Learning (COL). Retrieved from URL:http://oasis.col.org/bitstream/handle/11599/1740/201 5 COL Gender-Bias-Quiz.pdf? sequence $=3$ \&isAllowed $=y$

5. Hill, C. (2016). Barriers and Bias: The Status of Women in Leadership. Retrieved from URL: https://www.aauw.org/research/barriers-and-bias/

6. Lacan, J. (1972). On feminine sexuality: the limits of love and knowledge: Book XX : Encore, 1972.

7. Project Implicit / Implicit Association Test (IAT). Retrieved from URL: https://implicit.harvard.edu/implicit/aboutus.html

8. Taylor, J.S., Bogdan, R. \& DeVault, L.M. (2015). Introduction to Qualitative Research Methods. A Guidebook and Resource. NJ: John Wiley \& Sons.

9. Webb, E. J. (1973). Unobtrusive Measures: Nonreactive research in the social sciences. Chicago: McNally.

\section{References}

1. Auster, C. J., \& Ohm, S. (2000). Masculinity and femininity in contemporary American society: A reevaluation using the Bem Sex-Role Inventory. Sex Roles, 43, 499-528.

2. Bem S. (1993). The Lenses of Gender: Transforming the Debate on Sexual Inequality. Yale University Press.

3. Ferrer-Pérez, V. A. (2014). The measure of the masculinity-femininity construct today: Some reflections on the case of the Bem Sex Role Inventory. Revista de Psicología Social 
29(1): 180-207, 2014. DOI: 10.1080/02134748.2013.878569

4. Gender, Bias Quiz (2015). The Institutional Scorecard for Gender Mainstreaming / written by K. Tezare; edited by R. Wong. Commonwealth of Learning (COL). Retrieved from URL:http://oasis.col.org/bitstream/handle/11599/1740/2015_COL_Gender-BiasQuiz.pdf? sequence $=3$ \&isAllowed $=\mathrm{y}$

5. Hill, C. (2016). Barriers and Bias: The Status of Women in Leadership. Retrieved from URL: https://www.aauw.org/research/barriers-and-bias/

6. Lacan, J. (1972). On feminine sexuality: the limits of love and knowledge: Book XX : Encore, 1972.

7. Project Implicit/ Implicit Association Test (IAT). Retrieved from URL: https://implicit.harvard.edu/implicit/aboutus.html

8. Taylor, J.S., Bogdan, R. \& DeVault, L.M. (2015). Introduction to Qualitative Research Methods. A Guidebook and Resource. NJ: John Wiley \& Sons.

9. Webb, E.J. (1973). Unobtrusive Measures: Nonreactive research in the social sciences. Chicago: McNally.

\title{
ANALYSIS OF STANDARDIZED PSYCHODIAGNOSTIC INSTRUMENTS IN THE FIELD OF GENDER RESEARCH Tetiana Kostina \\ PhD in Psychology, Associate Professor, Doctoral student of the Department of Psychology \\ Pereiaslav-Khmelnytskyi Hryhorii Skovoroda State Pedagogical University \\ 30, Sukhomlynskyi Str., Pereiaslav, Ukraine, 08401 \\ kostina tanya@ukr.net, https://orcid.org/0000-0001-9644-0630
}

\begin{abstract}
The article deals with the analysis of methodological tools used in the field of gender studies. A theoretical analysis of the possibilities of using the methods and techniques used in Western psychology is conducted. In particular, the basic techniques currently used in the psychology of gender studies are presented: Bem Sex-Role Inventory (BSRI), Implicit Association Test (IAT), Gender Bias Quiz.

It is emphasized that when exploring gender sensitive issues (gender inequality, gender discrimination, gender imbalance, etc.), it is necessary to combine explicit research methods (direct questions, direct scaling, direct assessment) with implicit (obtaining necessary data based on indirect questions). Among the techniques analyzed in the paper, explicit ones include Bem Sex-Role Inventory (BSRI), Gender Bias Quiz; implicit methods include Implicit Association Test (IAT). The necessity of using reliable methods in the field of studying gender issues is actualized in the work (in particular, in the study of psychological features of a person's attitude to gender inequality). Of particular importance are methodical techniques and techniques that allow to obtain information provided by the respondent beyond the effect of social approval.

Research has shown that in the study of gender issues (gender stereotypes, attitudes toward gender inequality, gender imbalance, etc.) it is important to combine methods that allow to obtain both quantitative indicators (e.g., the level of gender bias) and qualitative ones that can be obtained using other methods, such as the content analysis method.
\end{abstract}

Keywords: explicit method, implicit method, gender, gender studies, gender methodological tools. 